\title{
PENERAPAN KRITERIA OPTIMUM CURRENCY AREA DAN VOLATILITASNYA: STUDI KASUS ASEAN-5 +3
}

\author{
Dimas Bagus Wiranata Kusuma \\ Arief Dwi Putranto ${ }^{1}$
}

\begin{abstract}
This paper is aiming to elaborate the case of how exchange rate volatility (ERV), which is supposedly considered to form optimum currency area (OCA), can be reduced in order justify the feasibility of the OCA idea within ASEAN5 plus three. Interestingly, the results provide some evidences that the ASEAN5+3 are considered not really ready to form OCA. It corroborates the existing opinion that the different in economic structure and its policies over foreign environment are becoming some barriers and challenging area to synchronize in the following time. The positive impacts AS to ERV which are incurred in ASEAN5+3 economies indicate the existence of inappropriate condition to form OCA since there are no similar shocks across a monetary union's participating countries. Under such condition, it would foster the costs of forgoing the exchange rate as a shock absorbing mechanism. It deserves to argue that those observed countries still are resisting their existing regime since they are till believing that they begin to establish the system of monetary which are able to absorb any possible shocks in regards of their SIZE. In sum, the ASEAN5+3 countries are considered to fulfilling the requirement to form currency optimum area which are able to main their stable currency.
\end{abstract}

JEL: D81, E52, F15, F36

Key words: Optimum Currency Area, a Single Currency, Exchange Rate Volatility, Stability

1 Dimas Bagus Wiranata Kusuma adalah mahasiswa pada program master Economics and Management Sciences International Islamic University Malaysia (dimas economist@yahoo.com), Arief Dwi Putranto adalah mahasiswa pada program sarjana di Economics and Management Sciences International Islamic University Malaysia (ariefdepee@hotmail.com). 


\section{PENDAHULUAN}

Setelah pengenalan Euro pada sebelas negara sebelas tahun lalu, dan tren yang meluas atas adopsi Euro yang berkelanjutan dengan meningkatnya negara partisipan, maka banyak studi yang dibuat tentang apakah replikasi pengalaman Euro dapat diaplikasikan khususnya pada area ASEAN-5 + 3. Hal ini menjadi sangat penting sejak krisis keuangan Asia pada tahun 1997/1998, di mana dominasi dollar untuk diadopsi sebagai rezim nilai tukar tidak dapat diandalkan untuk mendukung stabilitas keuangan. Beberapa pilihan alternatif muncul untuk menghadapi permasalahan ini, antara lain mematok pada mata uang pasak ${ }^{2}$ tertentu (baik mata uang tunggal atau keranjang mata uang), mengadopsi rezim nilai tukar fleksibel, atau serikat moneter (monetary union). Banyak usaha telah dilakukan, contohnya Chiang Mai Initiative (CMI) yang diumumkan oleh menteri keuangan negara ASEAN+3, yang dilaksanakan pada bulan Mei 2000. CMI dibuat untuk memfasilitasi pertukaran data dan informasi yang konsisten dan tepat waktu, dan untuk memfasilitasi pembentukan kesepakatan pembiayaan regional.

Pendekatan lain dilakukan untuk memperkuat ide integrasi adalah pembentukan Komunitas Ekonomi ASEAN (AEC) dan Perdagangan Bebas ASEAN (AFTA). Keduanya ditujukan untuk menciptakan ekonomi regional ASEAN yang stabil, sejahtera, dan kompetitif di mana aliran bebas barang, jasa, investasi, dan tenaga kerja terampil melalui penerapan simultan pemotongan tarif secara progressif melalui skema Common Effective Preferential Tariff (CEPT).

Tapi, keberadaan integrasi regional membutuhkan koordinasi makroekonomi antar negara dalam region tersebut. Maka dari itu, tujuan dari integrasi regional adalah untuk mempromosikan dan membantu perkembangan ekspansi pekerjaan untuk mensinkronkan siklus bisnis, dan akhirnya mengurangi guncangan dengan membagi kerugian dengan partner dagang dikarenakan kedua negara sama-sama memiliki claim atas output negara lain (Robert Mundel, 1973). Koordinasi intensif akan mempengaruhi kurangnya cakupan volatilitas makroekonomi yang dibawa oleh faktor-faktor seperti volitilitas nilai tukar (Frankel dan Wei, 1993). Uni Eropa dianggap sebagai model yang sukses dalam menjalankan integrasi ekonomi, di mana ketidakpastian nilai tukar dan ketidakteraturan dapat dihindari dan perdagangan serta investasi antar anggota meningkat secara substansial. (Ariccia, 1999).

Isu tentang integrasi tidak berbeda jauh dengan masalah mendesaknya stabilitas nilai tukar (ERS). Kenyataannya, ERS sangat penting pada segala usaha untuk meyakinkan stabilitas makroekonomi. Teori ekonomi menyarankan bahwa ketidakteraturan pada nilai tukar riil sebuah negara, sebagaimana permulaan mereka dari tingkat equilibrium jangka panjang, mempengaruhi pertumbuhan ekonomi secara negative. Kondisi-kondisi ini membuat ketidakpastian harga

2 Mata uang pasak, yakni mata uang yang dijadikan sebagai benchmark. 
relative, mencetuskan peningkatan kerugian pada penyesuaian dan penurunan efisiensi alokasi sumber daya pada pasar domestic (Kemme \& Teng, 2000). Maka dari itu, segala usaha untuk menstabilkan nilai tukar memungkinkan penciptaan lingkungan bisnis yang kondusif dan berpotensial untuk meningkatkan tingkat pertumbuhan ekonomi.

Setelah diketahui pentingnya isu di atas dalam mempromosikan kesejahteraan antar negara ASEAN, pertanyaan mengenai bagaimana volatilitas nilai tukar (ERV) dapat dikurangi menjadi penting. Krisis keuangan regional pada tahun 1997 hingga 1998 mengikis kredibilitas nilai tukar tetap unilateral, dan memperbaharui keinginan untuk integrasi moneter yang lebih besar dan stabilitas nilai tukar regional di Asia Timur (EA). Kesuksesan Euro juga meningkatkan bunga dalam kelangsungan hidup mata uang bersama untuk ASEAN dan negara maju di Asia Timur (Zhang, Sato, \& McAleer, 2004). Isu ini ditujukan untuk pertemuan ASEAN pada bulan November 1999 secara ekstensif, di mana 10 negara anggota yang mendesak untuk bekerja lebih keras untuk mencapai target common market dan mata uang tunggal (Asia Now, November 29, 1999; Hurley \& Santos, 2001).

Tetapi, pola kerangka institusi formal nampak kekurangan untuk mencapai integrasi moneter. Sebagai tambahan, kondisi keuangan dan ekonomi berbeda di antara negara-negara ASEAN. Meskipun begitu, harus dicatat bahwa ekonomi ASEAN telah mengalami integrasi regional yang sangat cepat pada dekade terakhir ini. Integrasi ini timbul sebagai hasil dari liberalisasi unilateral pasar barang dan modal.

Walaupun fakta bahwa menjumlahkan antara kerugian dan keuntungan serta menerapkan arahan optimum currency area (OCA) sulit, literatur menunjukkan bahwa ASEAN memiliki beberapa karakteristik yang mengatakan bahwa keuntungan menerapkan mata uang bersama mungkin cukup signifikan, bahkan relatif terhadap kerugian (Madhur, 2002). Secara keseluruhan gabungan OCA mengindikasikan regional memiliki kesamaan dengan Uni Eropa (Bayoumi \& Eichengreen, 1998). Indikasi ini termasuk dalam perdagangan intraregional, fleksibilitas harga, upah, mobilitas tenaga kerja, dan guncangan simetris. Dengan menggunkaan beberapa jenis indikator dari literatur OCA, Bayoumi dan Eichengreen (1998) menyimpulkan bahwa, berdasarkan pandangan ekonomi murni, ASEAN sangat cocok untuk OCA sebagaimana Eropa penting bagi Maastricht Treaty.

Selama periode post-Bretton Woods, negara-negara ASEAN5+3 mengalami ERV substansi walaupun mengadopsi rezim nilai tukar crawling peg. Antara tahun 1974 dan 1999, Rupiah Indonesia adalah yang paling sering berubah (Volatile) di antara mata uang ASEAN, diikuti oleh Peso Filipina, sementara Dollar Singapura adalah yang paling stabil (Hurley \& Samos, 2001). Tetapi, pada kasus ASEAN5+3, China telah mengalami volatilitas yang paling sedikit dikarenakan 


\begin{tabular}{|c|c|c|}
\hline \multicolumn{2}{|c|}{ Pertumbuhan 1998 (\%) } & \multirow{2}{*}{$\begin{array}{c}\text { Depresiasi (\%) } \\
85\end{array}$} \\
\hline Indonesia & $-1,4$ & \\
\hline Malaysia & $-6,5$ & 45 \\
\hline Filipina & $-0,5$ & 40 \\
\hline Singapura & 1,5 & 20 \\
\hline Thailand & $-8,0$ & 60 \\
\hline Cina & +6 & 0 \\
\hline Jepang & -2 & +8 \\
\hline Korea Selatan & $-6,8$ & 29 \\
\hline
\end{tabular}

telah menerapkan rezim peg atas US Dollar. Bukti lain tentang volatilitas mata uang ASEAN dapat ditemukan pada studi yang dilakukan oleh Nam dan Mc Aleer (2002), Lee dan Tan (2004). Dari Table IV.1, mata uang ASEAN pada umumnya nampak cukup rapuh dan sensitif terhadap guncangan tiba-tiba. Volatilitas, bagaimanapun juga bertentangan dengan Hurley dan Santos (2001). Walaupun hal ini berbeda, ternyata dua negara yang paling dipengaruhi oleh masalah volatilitas, Thailand dan Indonesia, juga menderita pertumbuhan ekonomi negative terbesar. China merupakan negara dengan volatilitas paling kecil di antara ASEAN-5+3, dan juga paling sedikit dipengaruhi oleh krisis ekonomi.

Pandangan populer antar ekonom dan pembuat kebijakan sejak krisis Asia adalah negaranegara berkembang dengan rekening modal terbuka memilliki solusi bipolar terhadap dilema nilai tukar: baik free floating (mengambang) atau hard peg (tetap). Solusi hard peg merujuk kepada penggunaan mata uang bersama atau formasi penyatuan moneter. Hochreiter and Winckler (1995) menggambarkan kerugian dan keuntungan melepaskan mata uang nasional dan bergabung pada penyatuan moneter. Diantara beberapa akibat yang telah digambarkan sehubungan dengan Euro adalah sebuah dorongan pertumbuhan ekonomi yang terjadi melalui peningkatan perdagangan (Rose, 2000; Frankel, \& Rose, 2002). Bergabung dengan perserikatan moneter juga memfasilitasi efisiensi mikroekonomi yang lebih besar dengan menghilangkan ERV, sehingga memperkecil tingkat suku bunga dan mempromosikan penggunaan mata uang internasional.

Setelah membahas stabilitas mata uang Singapura, kita akan mengkaji nilai tukar bilateral antara ekonomi negara-negara ASEAN-5 +3, seperti Malaysia, Thailand, Filipina dan Indonesia, Dollar Singapura, China, South Korea, dan Jepang. Ini adalah tujuan dari paper ini untuk terlebih dahulu menemukan penjelasan tentang volatilitas pada nilai tukar, dan pada akhirnya 
menentukan kelayakan mata uang tunggal negara regional ASEAN-5+3. Dengan sebuah definisi, jika variable-variabel OCA yang ditunjukkan pada studi ini secara signifikan menjelaskan variasi nilai tukar, mata uang bersama ASEAN-5+3 akan dianggap cukup sehat dan bahkan juga memperkuat pendapat tentang AFTA. Ini juga merupakan tujuan kami untuk mengkaji jika ada kebalikan hubungan sebab akibat pada hubungan tersebut; dengan kata lain, apakah ERV memiliki dampak pada kriteria OCA. Untuk memperkuat formasi OCA di negara-negara ASEAN$5+3$, mativasi terakhir kami adalah untuk mengidentifikasi kesulitan yang harus dihadapi oleh ASEAN-5+3 bahkan sebelum mereka memulai dengan menggunakan mata uang bersama.

Paper ini dirancang sebagai berikut. Bagian kedua dari paper ini akan menyajikan kajian tentang adanya literatur, dan termasuk definisi variable OCA. Bagian ketiga mengkhususkan model empiris bersama dengan perkiraan estimasinya. Hal ini juga diikuti oleh penilaian empiris model dengan hasil yang ditafsirkan pada bagian keempat. Sebagai tambahan, bagian empat sebagai jawaban dari tujuan ketiga, kami mengajukan pertanyaan kesulitan yang mungkin dihadapi oleh ASEAN-5+3 dalam membentuk mata uang bersama dengan sukses dan menjadi agenda ASEAN-5+3 untuk dikerjakan sebelum tujuan pembentukannya tercapai. Paper ini menyimpulkan pada bagian kelima dengan mengajukan beberapa pengamanan dan strategi that digambarkan sebagai kunci pembentukan OCA yang sukses.

\section{TEORI}

Kontribusi seminal oleh Mundell (1961) dan McKinnon telah muncul sebagai teori optimum currency area (OCA) sebagaimana kerjasama moneter dan nilai tukar antar negara. Mundell (1963) telah menunjuk beberapa negara yang secara simetris terpengaruh oleh guncangan merupakan kandidat utama dan sesuai untuk OCA. Selanjutnya, Mundell dan Mc Kinnon melalui penelitian mereka, menemukan sedikitnya empat keuntungan akan dicapai dengan mengadopsi mata uang bersama, yaitu:

1. Perluasan perdagangan akan terjadi jika anggota yang berpotensial dalam serikat sering berdagang satu sama lain dikarenakan keberadaannya sangat diharapkan akan mengurangi biaya transaksi.

2. Gangguan-gangguan akan terjadi apabila negara-negara tersebut mengalami guncangan yang sama jadi kerugian melepaskan independensi kebijakan moneter akan berkurang.

3. Tingkat mobilitas tenaga kerja terjadi jika mobilitas tenaga kerja yang tinggi antar batasanbatasan merupakan mekanisme yang berguna untuk menyesuaikan guncangan asimetris yang selanjutnya membawa dampak pengangguran tinggi pada subjek anggota serikat.

4. Transfer fiscal terjadi apabila terjadi guncangan-guncangan regional yang spesifik, sistem fiskal federal akan menyediakan asuransi regional (dalam bentuk keuntungan asuransi 
pembiayaan pengangguran secara federal), yang melemahkan dampak guncangan regional pada pendapatan interregional differensial.

5. Memasuki OCA juga menuntut disiplin negara-negara secara individual karena membebaskan bank sentral dari kebijakan yang akan menyebabkan inflasi.

6. Mengurangi gempuran yang bersifat spekulatif seperti negara dikuatkan dan juga dilindungi dari kebijakan ekonomi tidak teratur seperti "pengemis milik tetangga", yang apapun pelanggaran dalam melaksanakan kebijakan tersebut akan memberikan dampak negatif pada semua negara tersebut.

Frankel dan Rose (1998) memperdebatkan ide bahwa beberapa kriteria OCA yang dibahas dapat bersifat endogen. Begitu sekelompok negara membentuk sebuah area mata uang dengan menetapkan nilai tukar mereka, tingkat integrasi ekonomi intra area akan meningkat sejalan dengan tingkat guncangan ekonomi simetris. Maka dari itu, integari ekonomi yang lebih dalam dan guncangan simetris bukan merupakan prasyarat untuk membentuk area mata uang bersama atau tingkatan lain kerja sama moneter. Sebaliknya, jika negara-negara ini memperlihatkan komitmen politik yang kuat untuk mengkoordinasikan kebijakan moneter dan nilai tukarnya, maka usaha mereka untuk membentuk sebuah area mata uang bersama dapat berhasil selama mereka memenuhi kriteria OCA untuk langkah pertamanya.

Eichengreen and Bayoumi (1999) mencoba untuk menganalisis prospek ekonomi dan politik untuk integrasi moneter di Asia Timur, dan berdasarkan kriteria khusus, yang bernama perdagangan tingkat tinggi dan integrasi FDI, kecepatan penyesuaian kepada guncangan dan gangguan permintaan dan penawaran simetris, muncul dengan kesimpulan bahwa sebuah regional memenuhi standar kriteria OCA untuk mengadopsi mata uang kebijakan moneter bersama. Tetapi, masalah besar pada proses ini adalah isu mengorbankan otonomi moneter khususnya diberikan sistem keuangan yang lemah di sejumlah negara ini.

Melihat pola perdagangan yang meningkat di Asia, Kawai dan Motonishi (2005) menemukan bahwa pada dekade terakhir terdapat ekspansi perdagangan intra regional yang begitu cepat seperti halnya perdagangan intra-indsutri. Terlebih lagi, perdagangan intra regional sebagai saham perdagangan secara keseluruhan di Asia Timur telah meningkat dari 35\% pada 1980 menjadi 54\% pada 2003. Sehubungan dengan integrasi FDI, Jepang, US, dan Uni Eropa dianggap sama penting untuk investor asing di Asia Timur, dengan Jepang yang menjadi negara paling signifikan di regional ASEAN.

Terkait dengan tingkat integrasi pasar tenaga kerja nampaknya berbeda di antara negaranegara di regional. Ekonomi maju seperti Jepang dan Korea telah mempertahankan pembatasan ketat pada mobilitas tenaga kerja. Sementara itu, ekonomi Asia Tenggara seperti Malaysia, Thailand, Singapura, dan Indonesia dikategorikan memiliki mobilitas tenaga kerja yang tinggi. 
Eichengreen dan Bayoumi (1999) dan Goto dan Hamada (1994) mencatat bahwa pasar tenaga kerja lebih fleksibel di Asia dibandingkan Eropa di awal 1990 an.

Menurut seminal paper Mundell yang menyatakan bahwa sistem mata uang nasional berhubungan dengan adanya nilai tukar yang fleksibel. Selanjutnya, ia muncul dengan ide bahwa perlunya membentuk sebuah system mata uang di mana mata uang tidak terbatas secara nasional saja, tapi secara geografis dimana factor mobilitas cukup tinggi. Mundell, selanjutnya, menyangkal bahwa pilihan antara rezim nilai tukar yang tetap dan fleksibel seharusnya tidak independen pada karakteristik ekonomi di negara-negara atau area yang masih dalam pertanyaan (Tower dan Willett, 1976).

Berdasarkan teori OCA, kebijakan untuk bergabung dengan serikat moneter dapat diputuskan dengan menggunakan tiga faktor utama. Ini adalah bentuk perluasan intensitas perdagangan antar negara di area yang diajukan, simetri aktifitas ekonomi dan karakteristik spesifik sebuah negara (Ling, 2001). Mc Kinnon (1963) menyatakan bahwa sistem ekonomi terbuka yang tinggi yang direkomendasikan untuk memenuhi OCA sebagai mata uang bersama sangatlah penting untuk stabilitas dan kemakmurannya. Paper ini akan memperhatikan analisis adanya guncangan asimetris dan PDB negara-negara sebagai proksi untuk memenuhi kriteria untuk membentuk OCA.

Guncangan asimetris adalah elemen lain yang penting dalam teori OCA, dikarenakan cenderung mengikis masalah mata uang bersama. Menurut Frankel dan Mussa (1980), guncangan asimetris terjadi pada saat gangguan tak terduga mempengaruhi output nasional sebuah negara berbeda dengan yang lainnya. Literatur OCA menekankan bahwa guncangan yang sama antar negara-negara yang bergabung dalam serikat moneter mengurangi kerugian pembatalan nilai tukar seperti sebuah guncangan yang mengganggu mekanisme. Di sisi lain, retensi nilai tukar sebagai instrument kebijakan yang independen adalah sangat penting jika sebuah negara mengalami sebagian besar guncangan asimetris. (Ling, 2001). Pengurangan otonomi sebagai dampak dari kerugian kebijakan moneter independen pada penerapan OCA digambarkan akan sangat merugikan pada saat: (1) guncangan-guncangan makroekonomi lebih "asimetris", (2) kebijakan moneter adalah instrument yang kuat untuk mengoffset guncangan seperti itu, dan (3) mekanisme penyesuaian lain, seperti upah relative dan mobilitas tenaga kerja, kuang efektif (Eichengreen, 1997).

Pada studi ini, Mundell menyarankan bahwa mata uang bersama dapat mengurangi guncangan asimetris karena melibatkan pendapat negara-negara lain dan banyak portofolio investasi yang berbeda. Dalam perserikatan moneter, sebuah negara yang mengalami guncangan yang kurang baik secara efektif membagi kerugiannya dengan partner dagangnya, karena partner mengakui output satu sama lain melalui mata uang bersama. Bagaimanapun juga, di 
bawah nilai tukar yang fleksibel, tidak ada diversifikasi portofolio semacam itu dan sebuah negara yang mengalami guncangan yang kurang baik mengalami devaluasi. Mata uang domestik dan asetnya akan membeli dengan harga di bawah pasar dunia dan kerugian akibat guncangan akan dibatasi secara meluas pada negara di mana guncangan berasal. Pendeknya, kita menyimpulkan adanya hubungan positif antara guncangan asimetris dan ERV.

Adanya teori OCA utamanya berhubungan dengan pilihan rezim nilai tukar. Mereka juga cenderung untuk berfokus kepada variable spesifik negara yang tidak sering merubah dari waktu ke waktu. Devereux dan Lane (2003) mengajukan penggunaan ukuran relatif produk domestik bruto (PDB) dua negara sebagai proksi untuk ukuran. Ukuran, diukur sebagai log dari produk PDB negara $i$ dan $j$, dapat dianggap proksi untuk keuntungan mikroekonomi stabilitas nilai tukar. Dengan kata lain, negara-negara yang lebih kecil diharapkan untuk tidak mentoleransi fluktuasi pada nominal nilai tukarnya. Maka dari itu, kami mengharapkan hubungan posotif antara ERV dan PDB negara.

\section{METODOLOGI}

Sebagaimana disebutkan di atas bahwa studi ini adalah untuk menginvestigasi hubungan antar variable ERV dan OCA, contohnya guncangan asimetris dan ukuran. Tujuan kami adalah untuk membenarkan kelayakan ide OCA dalam ASEAN5+3. Model empiris kami dispesifikasikan sebagai berikut:

$$
\mathrm{ERVt}=\beta \mathrm{o}+\beta 1 \mathrm{OCAt}+\mu \mathrm{t}
$$

Di mana, ERC diatur sebagai volatilitas nilai tukar nominal dan optimum currency area (OCA). Dengan mensubtitusikan proxy untuk OCA, kita akan mendapatkan:

$$
\mathrm{ERVt}=\beta \mathrm{o}+\beta 11 \mathrm{ASt}+\beta \mathrm{o} \ln \mathrm{SIZEt}+\mu \mathrm{t}
$$

AS mewakili guncangan asimetris, dan hubungan positif diperkirakan di antara faktor ini dan ERV. Makin tinggi tingkat AS antar dua negara, makin dalam pengaruh kurang baik terhadap keinginan suatu negara untuk memiliki mekanisme penyesuaian atau nilai tukar yang fleksibel untuk menyerap dan mengurangi dampak guncangan. Sementar itu, ukuran mengindikasikan interaksi antara PDN inti sebuah negara dan sesuai dengan negara-negara ASEAN-5+3. Sebagaimana disebutkan oleh Deveruex dan Lane (2003), variable ini adalah sebuah proksi untuk karakteristik spesifik sebuah negara dan mencatat bahwa negara yang lebih kecil tidak akan bisa untuk mentolerir variasi nilai tukar. Maka dari itu, kami mengharapkan tanda tersebut menjadi positif. 
ERV diukur sebagai rata-rata bergerak nilai tukar yang pertama dibedakan dengan order tiga $(m=3)$, sebagai berikut:

$$
E R V_{t}=\left[\left(\frac{1}{m}\right) \sum_{i=1}^{m} E R_{t-1-i}-E R_{t-1}\right]
$$

Pengukuran AS cukup sama dengan pengukuran ERV. AS diproksikan dengan menggunakan nilai differensial pertumbuhan absolut, atau:

$$
A S_{t}=\left[\left(\text { growth }_{k, t}-\text { growth }_{j, t}\right)^{2}\right]^{2}
$$

Dimana subscrip $k$ dan $j$ bertahan untuk negara $k$ dan $j$, masing-masing.

Banyak bentuk data ekonomi berkala menunjukkan fitur umum seperti periode stasioner. Tapi, akhir-akhir ini pakar ekonometri berkala telah memformulasikan konsep pergerakan bersama pada frekuensi khusus dala model ekonometri, bersama dengan pendapat bahwa factor umum dapat mempengaruhi tren beberapa komponen variable makroekonomi. Meskipun begitu, statistik penyokong analisis berkala mengharuskan data stasioner. Hal ini akan mensyaratkan perbedaan pertama untuk kebanyakan makroekonomi berkala sebelum memperkirakan model ekonomi. Maka dari itu signifikansi mendeteksi dan mengoreksi tren komponen dalam data makroekonomi cukup terindikasi.

Jika dua atau lebih variable memiliki trend umum, maka hubungan sebab akibat pasti ada paling tidak satu arah. Banyak seri, bahkan yang tidak stasioner, pada saat dikaji secara terpisah, akan menampakkan hubungan equilibrium jangka panjang jika mereka bergabung secara linear (Engle \& Granger, 1987). Maka dari itu, kedua seri tersebut disebut terkointegrasi. Test kointegrasi berhubungan dengan perilaku jangka panjang elemen waktu berkala nonstasioner secara parsial ini adalah indikasi kecenderungan umum sebuah komponen. Dengan kata lain, kointegrasi adalah pendekatan statistik yang menguji keberadaan hubungan ekuilibrium jangka panjang antar variable non-stasioner yang terintegrasi pada urutan yang sama. Dua seri non-stasioner dikatakan terintegrasi jika ada kombinasi linear dua seri tersebut. Untuk tujuan ini, Johansen dan Juselius (1990) telah memperkenalkan dua tes rasio kemungkinan untuk menentukan jumlah vector yang terkointegrasi, yang disebut eigenvalue maksimum dan trace test.

Namun demikian, setelah diberikan sifat alami dari variable OCA, juga penting untuk menganalisis hubungan jangka pendek dinamis antar variabel dalam studi ini. Kointegrasi antara dua atau lebih variabel yang cukup mengindikasikan hubungan sebab akibat pada setidaknya satu arah (Granger 1988). Hubungan sebab akibat antara pra-penetapan dan variabel dependen dapat dikaji dengan mengadakan Wald test, yaitu dengan menghitung $\mathrm{F}$ statistik bedasarkan hipotesis null yang mana sejumlah koefisien pada nilai lagged variabel independen sama dengan 
nol. Jika hipotesis null diterima, dapat disimpulkan bahwa variabel independen tidak menyebabkan variabel dependen.

Hubungan jangka panjang antara ERV dan OCA diuji dengan menggunakan prosedur kointegrasi. Tujuh tipe nilai tukar telah dipilih, yaitu Yuan/SD, Yen/SD, Won/SD, RM/SD, Bath/ SD, Peso/SD, dan Rp/SD, di mana kepanjangan SD adalah Dollar Singapura. Nilai-nilai ini dicatat selama periode 1970 hingga 2008, bersama dengan data PDB setiap negara dengan menggunakan data yang dikumpulkan dari Statistik Keuangan Internasional, sebuah publikasi International Monetary Fund (IMF)

\section{HASIL DAN ANALISIS}

Hasil dari akar unit yang diuji berdasarkan Philip-Perron (1988) menunjukkan bahwa secara umum, seluruh variabel tidak stasioner pada level di setiap negara. Penggunaan prosedur error vector correction sesuai, telah diberikan bukti bahwa umumnya seluruh variabel nampaknya terintegrasi pada urutan I atau I(I). Tabel IV.2. menyajikan hasil tes kointegrasi, ditunjukkan oleh jejak yang signifikan dan uji eigenvalue yang maksimal. Dari hasil uji kointegrasi Johansen, hipotesis null non-kointegrasi ditolak pada level signifikansi 0.01 untuk 2 negara, yaitu Thailand Bath dan Peso Filipina. Sisanya nampaknya tidak menunjukkan tidak adanya kointegrasi sehingga dianggap tidak memiliki ekuilibrium jangka panjang. Kesimpulan keseluruhan hasil disajikan pada Tabel IV.2.

Estimasi error correction model (ECM) untuk tiap persamaan disajikan pada Panel I Table IV.3. Disajikan bukti lebih jauh bahwa ada ekuilibrium jangka panjang antar variabel. ECT menggambarkan proses penyesuaian terhadap ekuilibrium jangka panjang ini. Dari Panel II Tabel IV.4, ternyata standar regresi eror pada umumnya rendah. Ketahanan model dinyatakan oleh uji diagnostic, termasuk uji LM (Breusch-Godfrey serial uji korelasi), uji ARCH (uji heterogenitas), uji Jacque-Bera (uji normalitas) dan uji CUSUM (tes stabilitas) dibawah nilai kritis 1\%. Dari ECM, nampak periode lagged error correction term (ECT) apda setiap persamaan terlibat secara signifikan dengan tanda yang benar dan besar. Tapi, berdasarkan hasil tersebut, kita dapat menjelaskan bahwa tidak semua negara dalam regional menunjukkan tanda yang benar dan besar sebagaimana diperkirakan pada hipotesis awal. Bath Thailand, Peso Filipina, Ringgit Malaysia, Won South Korea, and Yen Jepang Nampak sebagai tanda yang tiak signifikan karena PDBnya dan adanya guncangan asimetris antar negara. Maka dari itu, disajikan beberapa bukti bahwa ASEAN5+3 dianggap tidak siap untuk membentuk OCA. Ini memperkuat adanya pendapat bahwa perbedaan struktur ekonomi dan kebijakannya di seluruh lingkungan asing menjadi hambatan dan tantangan untuk mensinkronkan pada waktu berikut ini. 


\begin{tabular}{|c|c|c|c|c|c|c|c|c|}
\hline & & Mode & $\begin{array}{l}\text { Tabel } \\
\text { el ECM Dan } \\
\text { PANEL I : EC }\end{array}$ & $\begin{array}{l}\text { IV.2 } \\
\text { Diagnostic } \\
\text { M MODEL }\end{array}$ & & & & \\
\hline $\mathrm{D}(\mathrm{ERV}) \mathrm{BS}=$ & $\begin{array}{r}0.079688940 \\
0.058 \\
4.617901834 \mathrm{e}-\end{array}$ & $\begin{array}{l}27 *(\text { ERV }(-1) \\
41237222) \\
5 * D(A S(-1))\end{array}$ & $\begin{array}{r}0.038 \\
0.7547\end{array}$ & $\begin{array}{l}11963099 * G D \\
382605 * D(E R V \\
0.0001200149\end{array}$ & $\begin{array}{l}(-1) \\
(-1)) \\
846\end{array}$ & + & $\begin{array}{r}0.0044645396 \\
.01428315065 *\end{array}$ & $\begin{array}{l}19 * A S(-1)+ \\
(G D P(-1))+\end{array}$ \\
\hline$D(E R V) P S=$ & $\begin{array}{r}0.038717540 \\
0 . \\
6.765507364 \mathrm{e}-\end{array}$ & $\begin{array}{l}57 \text { ( ERV }(-1) \\
10231822) \\
5 * D(A S(-1))\end{array}$ & $\begin{array}{r}0.052 \\
0.7572\end{array}$ & $\begin{array}{l}62315102 * G D \\
955332 * D(E R V \\
3.278425301\end{array}$ & $\begin{array}{l}(-1) \\
(-1)) \\
-05\end{array}$ & + & $\begin{array}{r}0.0070458979 \\
.01735784436 *\end{array}$ & $\begin{array}{l}71 * A S(-1)- \\
(G D P(-1))\end{array}$ \\
\hline $\mathrm{D}(\mathrm{ERV}) \mathrm{RS}=$ & $\begin{array}{r}0.0024448964 \\
00097395718 \\
0.04292235592\end{array}$ & $\begin{array}{l}9 *(\text { ERV }(-1) \\
91315639) \\
1 * D(A S(-1)) \\
* D(G D P(-2))\end{array}$ & $\begin{array}{r}0.4 \\
0.03867 \\
4.556830\end{array}$ & $\begin{array}{r}449241465 * A \\
840317 * D(E R V \\
545 e-06 * D(A S \\
0.002233502\end{array}$ & $\begin{array}{l}(-1) \\
(-1)) \\
(-2)) \\
854\end{array}$ & $\begin{array}{l}- \\
+ \\
+\end{array}$ & $\begin{array}{r}1.02487665 \\
0.6587205498 * \\
0.0384236329 *\end{array}$ & $\begin{array}{l}3{ }^{*} \mathrm{GDP}(-1)+ \\
(\mathrm{ERV}(-2))+ \\
(\mathrm{GDP}(-1))-\end{array}$ \\
\hline $\begin{array}{r}\mathrm{D}(\mathrm{ERV}) \mathrm{RSS}=- \\
\quad 0.0\end{array}$ & $\begin{array}{r}0.0064407889 \\
0.32 \\
0005838300632\end{array}$ & $\begin{array}{l}11 *(\operatorname{ERV}(-1) \\
57259378) \\
* \mathrm{D}(\mathrm{GDP}(-1))\end{array}$ & $\begin{array}{r}0.001 \\
0.5775\end{array}$ & $\begin{array}{l}809625807 * A \\
751067 * D(E R V \\
1.554889872\end{array}$ & $\begin{array}{l}(-1) \\
(-1)) \\
-05\end{array}$ & + & $\begin{array}{l}.000445496686 \\
131529969 e-06\end{array}$ & $\begin{array}{l}{ }^{*} \mathrm{GDP}(-1)+ \\
{ }^{*}(\mathrm{AS}(-1))+\end{array}$ \\
\hline $\mathrm{D}(\mathrm{ERV}) \mathrm{WS}=$ & $\begin{array}{r}-0.15185403 \\
0.32 \\
1.623566172 \mathrm{e}-\end{array}$ & $\begin{array}{l}44^{*}(\mathrm{ERV}(-1) \\
51849436) \\
6 * \mathrm{D}(\mathrm{AS}(-1))\end{array}$ & $\begin{array}{l}0.0013 \\
0.3481\end{array}$ & $\begin{array}{r}89074651 * G D \\
845398 * D(E R V \\
9.640797512\end{array}$ & $\begin{array}{l}(-1) \\
(-1)) \\
-05\end{array}$ & $\begin{array}{l}+ \\
+0.00\end{array}$ & $\begin{array}{l}1.417262268 \mathrm{e} \\
03733364994 *\end{array}$ & $\begin{array}{l}05 * A S(-1)+ \\
(G D P(-1))+\end{array}$ \\
\hline $\mathrm{D}(\mathrm{ERV}) \mathrm{YeS}=$ & $\begin{array}{r}0.0030217665 \\
0.33 \\
.003276657145 \\
8.735769183 \mathrm{e}-\end{array}$ & $\begin{array}{l}6 *(\text { ERV }(-1) \\
12831701) \\
* D(G D P(-1)) \\
6 * D(A S(-2))\end{array}$ & $\begin{array}{rr}+ & 0.0086 \\
+ & 0.8014 \\
+ & 0.001065 \\
+ & \end{array}$ & $\begin{array}{l}75900519 * G D \\
657752 * D(E R V \\
110035 * D(G D P \\
0.0002205816\end{array}$ & $\begin{array}{l}(-1) \\
(-1)) \\
(-2)) \\
598\end{array}$ & $\begin{array}{l}+ \\
-\end{array}$ & $\begin{array}{r}0.013417990 \\
1.053775292 * \\
375997146 \mathrm{e}-05\end{array}$ & $\begin{array}{l}56 * A S(-1)+ \\
(\operatorname{ERV}(-2))+ \\
{ }^{\circ}(A S(-1))+\end{array}$ \\
\hline$D(E R V) Y S=$ & $\begin{array}{r}-0.02537267 \\
0.6 \\
0.0011041370 \\
0.04310754547\end{array}$ & $\begin{array}{l}52 *(\text { ERV }(-1) \\
29455274) \\
9 * D(A S(-1)) \\
* D(G D P(-2))\end{array}$ & $\begin{array}{rr}- & 0.04 \\
+ & 0.6689 \\
- & 0.000243 \\
- & \end{array}$ & $\begin{array}{r}092951236 * A \\
452318 * D(E R V \\
6604594 * D \text { (AS } \\
0.008059261\end{array}$ & $\begin{array}{l}(-1) \\
(-1)) \\
(-2)) \\
714\end{array}$ & $\begin{array}{l}+ \\
-\end{array}$ & $\begin{array}{r}0.17393160 \\
0.2411002694 * \\
02355093915^{*}\end{array}$ & $\begin{array}{l}{ }^{*} \mathrm{GDP}(-1)+ \\
(\mathrm{ERV}(-2))- \\
(\mathrm{GDP}(-1))\end{array}$ \\
\hline & & IeI II : & del Krite & and & In & nostik & & \\
\hline & BS & PS & RS & RsS & & WS & Yes & YS \\
\hline$R^{2}$ & 0,8694 & 0,8938 & 0,8995 & 0,5107 & & 0,3409 & 0,3317 & 0,612656 \\
\hline S.E. of regression & 0,004105 & 0,016309 & 0,024829 & 0,000599 & &, 000587 & 0,000754 & 0,103822 \\
\hline Autocorrelation & $\begin{array}{l}69,46961 \\
(0,00000)\end{array}$ & $\begin{array}{r}(0,000) \\
37,80389\end{array}$ & $\begin{array}{r}35,20948 \\
(0,0000)\end{array}$ & $\begin{array}{r}(0,000) \\
139,4289\end{array}$ & & $\begin{array}{l}30,72313 \\
0,00000)\end{array}$ & $\begin{array}{l}(0,00000) \\
93,06854\end{array}$ & $\begin{array}{l}49,09658 \\
(0,00000)\end{array}$ \\
\hline Heterogeneity & $\begin{array}{l}38,94341 \\
(0,00000)\end{array}$ & $\begin{array}{r}(0,000009) \\
47,84354\end{array}$ & $\begin{array}{l}99,01281 \\
(0,00000)\end{array}$ & $\begin{array}{r}(0,0000) \\
21,22666\end{array}$ & & $\begin{array}{l}1,894151 \\
0,00005)\end{array}$ & $\begin{array}{r}(0,033379) \\
100,4101\end{array}$ & $\begin{array}{r}290,3209 \\
(0,0000)\end{array}$ \\
\hline Normality & $\begin{array}{r}0,899722 \\
(0,000575)\end{array}$ & $\begin{array}{r}(0,637717) \\
13,35481\end{array}$ & $\begin{array}{r}1,3333434 \\
(0,001259)\end{array}$ & $\begin{array}{r}(0,513391) \\
2,195206\end{array}$ & & $\begin{array}{r}, 527106 \\
, 333670)\end{array}$ & $\begin{array}{r}(0,282648) \\
1,061882\end{array}$ & $\begin{array}{r}14,92102 \\
(0,588051)\end{array}$ \\
\hline
\end{tabular}

Notes : Figure in ( ) p-value and the test is based on F-Test

$\mathrm{BS}=$ Bath/SD,PS = Peso/SD, RS = Ringgit/SD, RsS = Rupiah/SD, WS = Won/SD, YeS = Yen/SD, YS = Yuan/SD, SD = Singapore Dollar

$\star * *, * *, *$ are McKinnon $99 \%, 95 \%$, and $90 \%$ critical values, respectively 


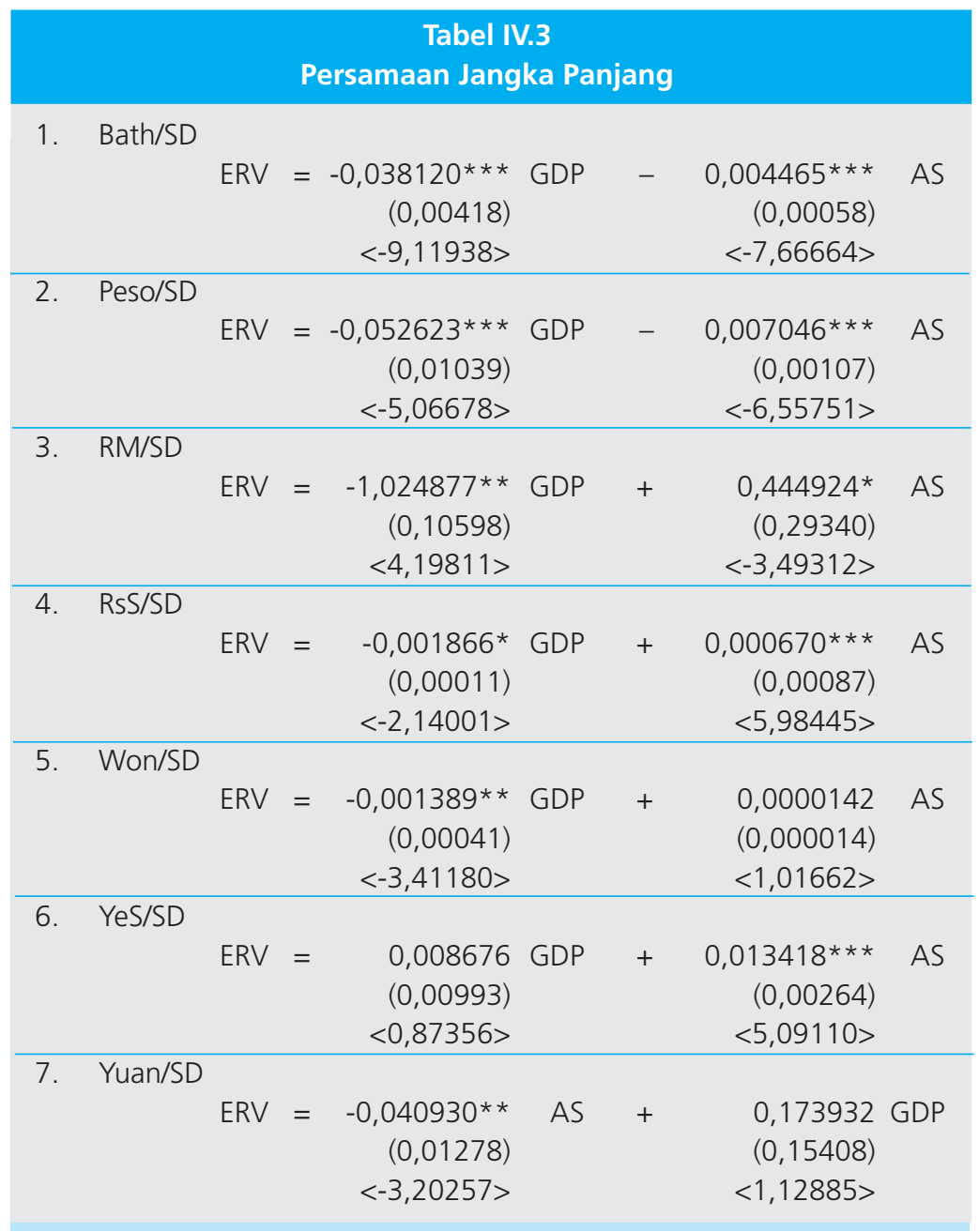

Melangkah ke dampak AS, nampak bahwa kontribusinya terhadap volatilitas relative cukup tinggi, karena negara industry baru seperti China dan Korea Selatan memulai membantu perkembangan dan memperluas ukuran dan cakupan ekonominya untk lebih kompetitif. Intensitas perdagangan negara tersebut telah menambah kemungkinan guncangan asimetris antar negara dalam regional. Persamaan tersebut juga menggambarkan bahwa kinerja ekonomi Malaysia, Indonesia, Jepang, Korea Selatan, dan China sama dengan kinerja ekonomi Singapura, yaitu menyangkut gangguan tak terduga mempengaruhi output nasional sebuah negara berbeda dengan yang lainnya (Frankel dan Mussa, 1980). Perkembangan ini dapat dijelaskan dengan persamaan struktur produksi ekonomi ASEAN, sebagaimana dengan pergerakan parallel terhadap keterbukaan, contohnya, dalam bentukorintasi yang lebih berfokus untuk ekspor dan liberalisasi rekening modal. Sama halnya kontribusi AS terhadap ERV relatif rendah untuk Thailand dan Filipina. Maka dari itu, secara umum, tingkat AS yang diderita oleh ekonomi 
ASEAN5+3 tidak terlalu tinggi. Yang ada sebaliknya adalah guncangan simetris yang tinggi (Madhur, 2002). Pendeknya, dampak signifikan dan positif AS pada ERV menyarankan adanya sedikit perbedaan sekilas antara Singapura dan ekonomi ASEAN5+3nya. Pengamatan ini juga mengimplikasikan kebutuhan penyesuaian pada saat kondisi ekonomi partner dagang berubah secara tak terduga. Maka dari itu, kami dapat menyimpulkan bahwa negara-negara ASEAN5+3 tidak sesuai untuk membentuk sebuah serikat moneter dibawah konsep optimum currency area sehubungan dengan peleburan guncangan asimetris. Sama halnya dengan hasil tersebut telah mengindikasikan fakta bahwa kemungkinan terjadinya guncangan asimetri mengimplikasikan fluktuasi pada stabilitas mata uang di negara lain dalam regional. Maka dari itu, dampak positif AS terhadap ERV yang terjadi di ekonomi ASEAN5+3 mengindikasikan adanya kondisi yang tidak sesuai untuk membentuk OCA karena tidak ada guncangan yang sama antar negara serikat moneter. Dalam situasi seperti itu, ini akan menambah kerugian pembatalan nilai tukar sebagaimana guncangan mengganggu mekanisme.

Pada semua kasus, SIZE memainkan peranan yang sangat kecil dalam menjelaskan ERV riil. Dampaknya nampak pada tanda yang benar dan besar sebagaimana diperkirakan sebelumnya pada semua negara yang diobservasi kecuali kasus Yen dalam hubungannya dengan SD. Persamaan-persamaan menunjukkan hasil yang kecil dan elemen SIZE negative. Hal ini mengindikasikan bahwa ekonomi cukup besar untuk menyerap segala guncangan. Setelah diberikan nilai koefisien mereka yang relative cukup kecil, kita dapat menyimpulkan bahwa ada suatu pertumbuhan kecenderungan untuk ekonomi ASEAN5+3 untuk mengembangkan kemampuan mereka dalam mengendalikan guncangan sebagaimana kecenderungan untuk memiliki dan menerapkan rezim nilai tukar yang stabil. Dengan kata lain, negara-negara ASEAN5+3 berusaha untuk mempertahankan rezim nlai tukar mereka. Hal ini dapat membantah negara-negara yang diobservasi tersebut masih melindungi keberadaan rezim mereka mereka masih percaya bahwa mereka memulai membangun system moneter yang dapat menyerap segala kemungkinan adanya guncangan dalam hubungannya dengan SIZA mereka. Secera keseluruhan, negara-negara ASEAN5+3 dipertimbangkan untuk memenuhi persyaratan untuk membentuk currency optimum area yang dapat mempertahankan mata uangnya yang stabil.

Hasil dari uji hubungan sebab akibat Granger disajikan pada Table IV.4. Hubungan sebab akibat jangka pendek Granger berjalan khususnya dari ERV ke setiap kriteria OCA, walaupun dampak jangka pendek PDB dan AS hampir tidak signifikan pada kasus negara-negara ASEAN5 dan signifikan pada poin kritis terkait Yuan China, Taiwan Won, and Yen Jepang. Sementara itu, hubungan sebab akibat jangka pendek Granger yang berjalan dari setiap kriteria OCA ke ERV atau ke kriteria OCA lainnya tidak nyata. Maka dari itu, disekuilibrium jangka pendek dapat disebabkan oleh guncangan ERV. 
Kita mencoba untuk mengkaji kerasnya dampak ERV pada aktifitas ekonomi riil lebih dekat. Berfokus pada kolom kedua Tabel IV.4, hubungan sebab akibat jangka pendek Granger dari ERV ke dalam setiap kriteria OCA menjadi jelas. Tanda dalam kurung menandakan arah dampak ERV pada setiap kriteria OCA. Walaupun banyak studi yang menggunakan model VAR (seperti VECM) menginvestigasi arah dampak dengan menggunakan impulse response function (IRFs), kami memilih untuk tidak terlalu berfokus pada IRFs dan sebaliknya menjumlahkan koefisien dampak jangka pendek ERV. Metode dengan menjumlahkan akibat jangka pendek ini dengan menjumlahkan koefisien yang umumnya diambil sebagai bagian dari prosedur ARDL. Saat tidak ada lagi lebih dari satu lag model VAR, koefisien jangka pendek (atau dampak) diperkirakan dengan penjumlahan pembeda koefisien pertama, sementara signifikansi dampak diuji dengan menggunakan F-test berdasarkan prosedur uji Wald.

Berdasarkan uji Granger, kami menemukan hanya Thailand, Taiwan, Jepang, dan China yang membawa akibat jangka pendek terhadap variabel yang diamati. Sementara dampak jangka pendek ERV pada PDB dan AS positif pada negara tersebut. Sementara dalam kasus Thailand, PDB telah membengkak terhadap AS. Hal ini menyatakan bahwa ekonomi Thailand akan menderita guncangan melalui fluktuasinya pada PDB. Selanjutnya, Indonesia, Malaysia, dan Filipina nampaknya tidak memperlihatkan hubungan sebab akibat antara variabel OCA dan ERV.

Pada dasarnya, ERV, yang digunakan sebagai proksi untuk miskoordinasi, dapat berkontribusi untuk perbedaan yang lebih besar, bukan konvergensi, antara anggota ASEAN. Singkatnya, kami menemukan bahwa ERV telah secara umum memberikan kontribusi negatif terhadap tingkat kegiatan ekonomi riil. Baik secara umum dan secara empiris, kami menemukan bahwa semua variabel OCA memainkan peran penting dalam menjelaskan ERV, dan demikian halnya dalam memilih rezim nilai tukar. Pertanyaan yang kemudian muncul adalah mengapa gagasan mata uang tunggal atau bersama belum direalisasikan. Dari hasil empiris, penjelasan yang mungkin termasuk kekecilan, koordinasi, pilihan mata uang, serta imobilitas tenaga kerja.

Seperti disebutkan sebelumnya bahwa OCA adalah wilayah geografis di mana ia akan memaksimalkan efisiensi ekonomi untuk memiliki saham seluruh wilayah mata uang tunggal. Ini menggambarkan karakteristik optimal untuk penggabungan mata uang atau penciptaan mata uang baru. Teori ini sering digunakan untuk menyatakan apakah suatu daerah tertentu siap atau tidak menjadi serikat moneter, salah satu tahap terakhir dalam integrasi ekonomi. Dalam pengertian ini, keberhasilan membangun dari OCA di bidang ASEAN5 +3 negara.

Sebuah langkah sukses menuju OCA dasarnya perlu mengatasi sejumlah kendala yang biasanya berhubungan dengan integrasi ekonomi dan moneter yang lebih besar. Kita mungkin 


\begin{tabular}{|c|c|c|c|c|c|c|}
\hline & \multicolumn{2}{|c|}{ ERV } & \multicolumn{2}{|c|}{ AS } & \multicolumn{2}{|c|}{ GDP } \\
\hline & \multirow[t]{2}{*}{ Coefficient } & $p$-value & Coefficient & $p$-value & Coefficient & $p$-value \\
\hline & & & \multicolumn{2}{|c|}{ PANEL I : BATH/SD } & & \\
\hline \multirow{5}{*}{$\begin{array}{l}\text { ERV } \\
\text { AS } \\
\text { GDP }\end{array}$} & & & \multirow[t]{2}{*}{1,72914} & \multirow[t]{2}{*}{$(0,19707)$} & \multirow{3}{*}{$\begin{array}{l}0,89886 \\
0,29189\end{array}$} & \multirow{3}{*}{$\begin{array}{l}(0,34959) \\
(0,59243)\end{array}$} \\
\hline & 0,04836 & $(0,82722)$ & & & & \\
\hline & 0,29700 & $(0,58923)$ & $3,15227 *$ & $(0,08452)$ & & \\
\hline & \multicolumn{6}{|c|}{ PANEL II : PESO/SD } \\
\hline & Coefficient & $p$-value & Coefficient & $p$-value & Coefficient & $p$-value \\
\hline \multirow{5}{*}{$\begin{array}{l}\text { ERV } \\
\text { AS } \\
\text { GDP }\end{array}$} & & & \multirow[t]{2}{*}{1,31844} & \multirow[t]{2}{*}{$(0,25866)$} & \multirow{3}{*}{$\begin{array}{l}0,82326 \\
0,45759\end{array}$} & \multirow{3}{*}{$\begin{array}{l}(0,37043) \\
(0,50320)\end{array}$} \\
\hline & 1,89555 & $(0,17732)$ & & & & \\
\hline & 0,01467 & $(0,90429)$ & 2,08815 & $(0,15734)$ & & \\
\hline & \multicolumn{6}{|c|}{ PANEL III : RM/SD } \\
\hline & Coefficient & $p$-value & Coefficient & $p$-value & Coefficient & $p$-value \\
\hline \multirow{5}{*}{$\begin{array}{l}\text { ERV } \\
\text { AS } \\
\text { GDP }\end{array}$} & & & \multirow[t]{2}{*}{0,03771} & \multirow[t]{2}{*}{$(0,84716)$} & \multirow{3}{*}{$\begin{array}{l}0,06164 \\
0,52356\end{array}$} & \multirow{3}{*}{$\begin{array}{l}(0,80567) \\
(0,47414)\end{array}$} \\
\hline & 0,84635 & $(0,36388)$ & & & & \\
\hline & 0,31780 & $(0,57653)$ & 0,06873 & $(0,79474)$ & & \\
\hline & \multicolumn{6}{|c|}{ PANEL IV : RP/SD } \\
\hline & Coefficient & $p$-value & Coefficient & $p$-value & Coefficient & $p$-value \\
\hline \multirow{5}{*}{$\begin{array}{l}\text { ERV } \\
\text { AS } \\
\text { GDP }\end{array}$} & & & 0,09429 & $(0,76061)$ & 1,77070 & $(0,19190)$ \\
\hline & 0,13783 & $(0,71268)$ & & & 0,89416 & $(0,35084)$ \\
\hline & 0,51223 & $(0,47892)$ & 1,94263 & $(0,17217)$ & & \\
\hline & & & PANEL V : & ON/SD & & \\
\hline & Coefficient & $p$-value & Coefficient & $p$-value & Coefficient & $p$-value \\
\hline ERV & & & 5,77327 ** & $(0,02171)$ & 4,23840 ** & $(0,04702)$ \\
\hline AS & 0,01909 & $(0,89090)$ & & & 0,83545 & $(0,36696)$ \\
\hline GDP & 1,52615 & $(0,22492)$ & 0,00565 & $(0,94050)$ & & \\
\hline & & & PANEL VI & EN/SD & & \\
\hline & Coefficient & $p$-value & Coefficient & $p$-value & Coefficient & $p$-value \\
\hline ERV & & & $3,78689 *$ & $(0,05972)$ & $8,88667 * * *$ & $(0,00520)$ \\
\hline AS & $4,44807 * *$ & $(0,04217)$ & & & 1,00145 & $(0,32383)$ \\
\hline GDP & 0,39843 & $(0,53200)$ & 0,08091 & $(0,77774)$ & & \\
\hline & & & PANEL VII : & JAN/SD & & \\
\hline & Coefficient & $p$-value & Coefficient & $p$-value & Coefficient & $p$-value \\
\hline ERV & & & 0,07575 & $(0,78475)$ & $3,54110 *$ & $(0,06820)$ \\
\hline AS & $6,24871 * *$ & $(0,01727)$ & & & 1,96944 & $(0,16932)$ \\
\hline GDP & 7,03221 ** & $(0,01195)$ & 0,20367 & $(0,65456)$ & & \\
\hline
\end{tabular}

Notes : Figure in ( ) p-value uji berdasarkan F-Test. SD = Dolar Singapura

$* * *, * *,{ }^{*}$ McKinnon nilai kritis $99 \%, 95 \%$, dan $90 \%$, masing-masing.

telah melihat dari dekat beberapa kendala dalam rangka mengurangi hambatan dan menjaga jalur yang tepat dalam membentuk agenda OCA.

\section{IV.1. CMI Kerangka: Lembaga Lemah?}

Dalam setiap macam pengaturan nilai tukar resmi di suatu daerah perlu adanya mekanisme yang menyediakan beberapa tingkat pertahanan kolektif terhadap serangan spekulatif terhadap 
mata uang tunggal. Baru-baru ini Chiang Mai Initiative (CMI) yang telah berkembang dapat memberikan beberapa dukungan kelembagaan terhadap serangan spekulatif tersebut. Setelah mengadakan pertemuan di Chiang Mai bulan Mei 2000, Jepang, Cina dan Korea Selatan menandatangani perjanjian bilateral dengan lima negara anggota ASEAN dan membentuk jaringan perjanjian swap bilateral (BSas) yang bertujuan untuk sebuah kerjasama moneter yang lebih besar. Jaringan tersebut memungkinkan negara-negara peserta untuk menarik dana dari BSas masing-masing untuk jangka waktu 90 hari. Penarikan pertama dapat diperpanjang tujuh kali. Tingkat bunga yang berlaku dalam skema tersebut adalah LIBOR ditambah premi sebesar basis 150 poin untuk penarikan pertama dan pembaharuan pertama. Setelah itu, kenaikan premi sebesar basis 50 poin untuk setiap dua pembaharuan, dalam harga ceiling keseluruhan basis 300 poin. Swap mata uang sebesar lebih dari \$ 83 milliar pada bulan Juli 2007. Untuk mengurangi masalah moral hazzard, BSA swap ini dihubungkan dengan pengeluaran IMF. Sebuah negara hanya dapat meminjam hingga 20\% jika tidak di bawah program IMF.

Selain dari keuntungan yang dihasilkan dari swap nominal, sinyal dukungan politik dan dukungan ekonomi BSAs dalam hal terjadi kesulitan keuangan. Jika ACU adalah menjadi mata uang paralel yang layak, Chiang Mai Initiative harus memainkan peran yang sangat penting. Sayangnya, struktur CMI saat ini memiliki beberapa kekurangan yang dapat mengurangi efektivitas itu. Di dalam tubuh CMI saat ini bersifat bilateral. Penggunaan BSas memerlukan persetujuan dari masing-masing pemberi pinjaman. Dalam keadaan seperti itu, jika sejumlah anggota menolak untuk memberikan swap atau penyedia berbagai swap menginginkan persyaratan dan kondisi yang berbeda, CMI kehilangan efektivitasnya sebagai lender of last resort. Selain itu, diskusi dengan berbagai penyedia swap membuang waktu dan mengurangi negara yang menginginkan swap dari kemampuan untuk memperoleh pertahanan yang efektif dan cepat untuk melawan serangan spekulatif. Jadi langkah-langkah harus diambil untuk memultilateralisasikan pengaturan swap bilateral yang ada sehingga pengeluaran swap dibuat secara terpadu dan tepat waktu.

Fasilitas BSA hanya langkah kecil menuju kerja sama keuangan di wilayah tersebut. Ukuran saat ini fasilitas swap hanya sedikit meningkatkan kualitas sumber daya keuangan yang tersedia bagi negara-negara untuk membantu mereka memenuhi kebutuhan likuiditas mereka, dan tidak memadai untuk mencegah krisis keuangan seperti yang terjadi tahun 1997. Selain itu, hanya $20 \%$ dari fasilitas BSA yang tersedia untuk peminjam sedangkan sisanya $80 \%$ membutuhkan persetujuan IMF dan karenanya tunduk pada persyaratan-persyaratan IMF. Hubungan seperti ini menjaga hegemoni Amerika Serikat dalam kerangka keuangan regional, sesuatu yang negara-negara Asia tertarik untuk bahkan melanggarnya. 
Struktur saat ini CMI juga memastikan bahwa negara-negara peserta tidak merasakan kebutuhan mendesak untuk membentuk lembaga pusat untuk melakukan pengawasan regional. Tidak adanya badan pusat untuk mengelola sumber daya dan memonitor perkembangan keuangan di kawasan ini merupakan hambatan serius bagi evolusi dari proses pengambilan keputusan bersama. Menyadari kekurangan ini, ASEAN +3 menteri setuju untuk mengambil langkah-langkah untuk meningkatkan efektivitas CMI. Ini termasuk integrasi lebih lanjut dan peningkatan pengawasan ekonomi ASEAN +3 ke dalam kerangka CMI, definisi yang jelas dari proses aktivasi swap dan penerapan mekanisme pengambilan keputusan kolektif, peningkatan ukuran swap, dan perbaikan mekanisme pencairan

\section{IV.2. Pengawasan Kawasan yang Tidak Memadai}

Pengawasan regional kebijakan nasional yang efektif merupakan prasyarat bagi negaranegara yang mencoba untuk mengadopsi mata uang tunggal atau melakukan bentuk kerjasama moneter. Salah satu alasan utama untuk menghubungkan aktivasi BSA kepada IMF adalah karena ketersediaan mekanisme pengawasan yang kredibel dengan Reksa Dana untuk negaranegara anggota. Selama masa krisis Asia, kebutuhan seperti mekanisme pengawasan Asia diakui dan tujuannya adalah untuk menyusun sistem peringatan dini untuk mencegah terjadinya krisis serupa di masa mendatang serta membatasi dampak penularan lintas negara selama masa krisis Asia.

Negara ASEAN-5 +3 memiliki sistem proses pengawasan yang sudah ada dengan bantuan teknis dari Ekonomi Regional Monitoring Unit (REMU) dari ADB yang disebut Tinjauan Kebijakan Ekonomi dan Proses Dialog ASEAN+3. Proses ini meliputi persiapan laporan rahasia oleh staf $A D B$, yang ditinjau oleh para pembuat kebijakan negara-negara anggota. Laporan ini kemudian dibahas dalam rapat menteri keuangan dan dibawa keluar sebagai pernyataan menteri yang disepakati.

Struktur yang melekat pada seluruh tinjauan dan proses pengawasan mengungkap beberapa kekurangan mencolok. Pertama, karena staf tahu bahwa dokumen akhir akan diperiksa oleh berbagai menteri, kemungkinan akan sangat inofensif dan tidak mungkin untuk mendukung kebijakan negara-negara yang dapat mendestabilisasi wilayah tersebut. Seperti sebuah dokumen, seperti terlihat dari pernyataan para menteri baru-baru ini, tidak mungkin untuk mendorong diskusi tentang risiko baru mulai di regional. Selain itu, tidak seperti pengawasan IMF, proses ASEAN-5 +3 tidak menentukan isi informasi yang tepat yang harus diberikan pemerintah masing-masing. Akibatnya, informasi yang tersedia untuk berbagai anggota adalah berdasarkan kebijaksanaan dari negara yang melapor. Hal ini membuatnya 
sangat sulit untuk membuat perbandingan antara berbagai negara dan memberikan kesimpulan kebijakan terkait.

Kurangnya pengawasan independen dan kredibel untuk memantau perkembangan ekonomi dan keuangan di kawasan ini merupakan hambatan yang signifikan untuk integrasi ekonomi dan moneter yang lebih besar. Hal ini, tentu saja, bukan untuk menyatakan bahwa mekanisme pengawasan IMF, dasarnya dalam bentuk konsultasi Pasal IV, yang diputuskan lebih unggul. Namun, dibandingkan dengan mekanisme pengawasan ASEAN-5 +3 yang seperti gigi ompong, ada pelajaran yang mungkin penting untuk dipelajari dari sistem Reksa Dana yang telah di upgrade.

\section{IV.3. Pasar Obligasi yang Tertinggal.}

Sebuah pasar obligasi yang dalam dan berkembang dengan baik dapat memfasilitasi arus utang lintas negara secara tertib di kawasan. Ini merupakan prasyarat penting bagi ACU. Untuk itu, inisiatif pembentukan Asian Bond Fund (ABF) adalah sebuah langkah yang benar karena memungkinkan membawa ekonomi Asia dengan berbagai ukuran dan struktur ekonomi bersama-sama. Sebelas anggota Executives' Meeting of East Asia-Pacific Central Bank (EMEAP) sepakat pada tahun 2003 untuk membentuk ABF, dana investasi regional yang berinvestasi pada obligasi dalam mata uang dolar AS. Korpus awal adalah $\$ 1$ miliar dengan berbagai pemerintah yang secara sukarela berkontribusi sekitar $1 \%$ dari cadangan mereka. Dana seharusnya berinvestasi untuk obligasi yang diterbitkan oleh sektor publik delapan negaranegara maju seperti Australia, Selandia Baru dan Jepang yang hanya memberi pinjaman yang ke $A B F$.

Dengan negara-negara berbeda di regional yang menunjukkan berbagai tingkat defisit transaksi berjalan dan surplus, perkembangan pasar obligasi yang kuat akan memungkinkan penyerapan manfaat arus utang intra-regional. Namun, bentuk awal dari ABF memiliki masalah keterbatasan yang perlu diatasi untuk memastikan kerja sama keuangan yang lebih besar. Pertama, ABF dapat berinvestasi dalam obligasi dalam mata uang dolar dan tidak bisa menyelesaikan krisis kepailitan penerbit obligasi Asia dalam kasus yang membuat sebuah penurunan tajam dalam nilai mata uang Asia vis-'a-vis dolar AS seperti yang dialami oleh Thailand dan Korea selama krisis keuangan tahun 1997. Jadi ada masalah currency missmatch yang kritis. Kedua, mayoritas emiten obligasi milik sektor swasta, dan mereka cenderung menggunakan dana untuk investasi jangka panjang, sementara pemberi pinjaman luar negeri sebagian besar bersifat jangka pendek. Ketika kondisi bisnis atau perkiraan memburuk, kreditur asing cenderung mengurangi eksposur risiko dengan menarik dana, bisnis lokal terancam 
bangkrut. Jadi selain dari currency missmatch, Asian Bond Fund juga mengalami 'maturity mismatch'. 'Mismatch ganda' Ini adalah salah satu alasan utama krisis keuangan Asia pada tahun 1997.

Menyadari ancaman currency missmatch dan dengan tujuan untuk mempromosikan obligasi mata uang lokal mata uang, ABF 2 diperkenalkan pada bulan Desember 2004. Ini melibatkan pembelian sebesar \$2 miliar-mata uang Asia obligasi dalam mata uang sovereign dan quasi sovereign. ABF-2 juga memperkenalkan Pan-Asian Bond Index Fund (PAIF) dan Pendanaan Dana Obligasi. PAIF adalah dana indeks ikatan tunggal yang berinvestasi pada obligasi mata uang lokal yang diterbitkan oleh delapan negara. Di sisi lain, FBF terdiri dari dua tingkatan. Dana induk dibagi menjadi delapan dana sub, yang masing-masing berinvestasi dalam obligasi mata uang lokal yang diterbitkan di pasar masing-masing.

Ukuran sekali lagi adalah kelemahan utama dari inisiatif ini. Ukuran saat ini sebesar $\$ 2$ miliar tidak signifikan dibandingkan dengan kepemilikan cadangan atau persyaratan pembiayaan infrastruktur sebagian besar negara-negara ini. Kedua, Dana hanya mencakup delapan negara Asia termasuk beberapa anggota ASEAN serta ekonomi penting lainnya seperti India. Dengan demikian, ada cakupan yang luar biasa untuk meningkatkan baik cakupan dan ukuran pasar utang regional. Selain itu, karena terbatasnya pasokan berkualitas baik obligasi sovereign dan quasi-sovereign, inisiatif seperti ABF dapat benar-benar mendesak pembelian obligasi swasta yang membawa pada tidak adanya pembiayaan baru.

\section{IV.4. Kurs Rezim Beragam}

Pengalaman Eropa menunjukkan bahwa kehadiran sebuah rezim moneter yang bersama, yaitu mengejar stabilitas nilai tukar wilayah luas, memainkan peran kunci dalam evolusi kerjasama moneter yang lebih besar. Namun, negara-negara Asia mengikuti beragam rezim nilai tukar. Sementara sejumlah mata uang Asia termasuk India Rupee, Dolar Singapura, Thai Baht, dan Ringgit Malaysia dapat diklasifikasikan sebagai mengambang terkendali (managed floats), negara-negara lain mengikuti mekanisme nilai tukar yang berbeda. Dolar Brunei dan China Renminbi terus dipatok terutama untuk masing-masing Dolar Singapura dan Dolar AS. Di sisi lain, Yen Jepang, Korea Won, Indonesia Rupiah dan Peso Filipina yang bebas mengambang.

Pengaturan nilai tukar yang beragam di kawasan Asia mencerminkan tujuan yang berbeda dari pembuat kebijakan moneter. Hal ini bervariasi mulai dari memagu nilai tukar dengan negara lain dalam currency board system untuk mengimpor kebijakan moneter negara yang bersangkutan, mempertahankan nilai tukar dalam kondisi undervalued untuk mempromosikan ekspor yang menghasilkan pertumbuhan, sampai kepada penargetan inflasi 
secara eksplisit. Merekonsiliasi tujuan yang beragam seperti di wilayah ini pasti menjadi tugas yang menantang.

\section{IV.5. Ekonomi, Heterogenitas Sejarah dan Politik}

Saat berdebat untuk integrasi ekonomi yang lebih besar di Asia, sangatlah penting untuk mengawasi perbedaan politik, ekonomi dan sejarah antara negara-negara di kawasan ini. negaranegara Asia sangat berbeda dalam hal struktur ekonomi dan tingkat pembangunan. Perbedaan dalam PDB per kapita lebih tinggi daripada di Eropa atau Amerika Utara. Pada tahun 2006, Jepang dan Singapura PDB per kapita dalam hal PPP hampir 15 kali lipat dari Lao PDR. Demikian pula, pangsa ekspor dalam rentang PDB di bawah 15\% di Jepang untuk lebih dari 100\% di Malaysia dan Singapura. Beberapa negara seperti Cina dan ASEAN yang anggota baru telah secara ekstensif diatur sistem keuangan dan tidak mungkin untuk melepaskan kontrol operasional dalam waktu dekat.

Sementara di Eropa, Jerman mengambil peran utama dalam mendorong integrasi moneter, ada tidak adanya pemimpin yang jelas di wilayah Asia. Jepang adalah negara yang paling maju di wilayah ini namun memiliki masalah historis dengan negara-negara tetangga seperti China dan Korea yang belum selesai. Jadi setiap blok dengan Jepang sebagai satu-satunya pusat tidak mungkin untuk menemukan pengambil banyak di Asia. Cina, karena itu ukuran dan pertumbuhan yang mengesankan selama 25 tahun terakhir, bisa saja merupakan potensi yang lain. Namun, arsitektur keuangan yang relatif terbelakang, mata uang yg tdk dpt ditukar, dan bank sentral dengan otonomi terbatas dapat menjadi hambatan utama untuk klaim tersebut. Selain itu, China yang juga memiliki saham menjadimasalah yang belum terselesaikan dengan Korea dan India. Juga kemungkinan menghadapi persaingan dari India, yang pertumbuhan ekonominya besar dan berkembang pesat di regional, yang berusaha untuk muncul sebagai inti dari pengaturan mata uang regional.

Tidak adanya negara pusat sampai sekarang berarti bahwa kerjasama Asia perlu lebih mengandalkan pendekatan simetris. Kerjasama tersebut memerlukan komitmen yang kuat di wilayah politik yang luas. Heterogenitas yang luas antara negara-negara, bagaimanapun, menghambat pembinaan kesadaran berpolitik. Negara-negara Asia memiliki perbedaan luas dalam struktur sosial, dan sistem ekonomi, mulai dari ekonomi pasar matang seperti Jepang dan Korea untuk ekonomi dalam transisi seperti Cina, India dan Vietnam. Meskipun begitu, negara-negara tersebut beberapa tahun terakhir telah bekerjasama dalam bidang keamanan dan kepentingan strategis, sisa Perang Dingin mungkin masih menghambat kerjasama ekonomi dan moneter yang lebih besar. Salah satu masalah utama dalam hal ini adalah hubungan- 
hubungan strategis yang banyak negara di wilayah ini dengan Amerika Serikat, yang mungkin membuat ambiguitas dalam mengejar regionalisme Asia. Tidak ada keraguan mengenai apakah regionalisme akan memberikan manfaat lebih besar daripada multilateralisme di kawasan ini. Pendapat tersebut telah mempengaruhi beberapa negara di Asia dan sedikit sulit membangun konsensus politik yang dibutuhkan untuk kerjasama yang lebih erat. Proses ini menjadi lebih sulit karena perbedaan luas dalam sistem politik dan lembaga di regional (misalnya pemerintah non-demokratis di Cina dan Myanmar dan demokrasi yang matang di India, Jepang dan Korea).

\section{STRATEGI}

Sebuah langkah sukses menuju unit mata uang Asia perlu untuk mengatasi kendala di atas. Jadi sebuah pergerakan perlu didukung oleh dua faktor. Pertama, perlindungan kelembagaan tertentu harus diciptakan atau memperkuat yang sudah ada, untuk mencegah negara-negara lain melepaskan diri dari aturan tersebut. Kedua, strategi perlu dirancang untuk mempromosikan penggunaan dan penerimaan mata uang paralel ini. Kami mencantumkan beberapa perlindungan dan strategi yang menurut pendapat kami merupakan kunci bagi keberhasilan ACU.

\section{V.1. Review periodik Satuan Mata Uang Asia (ACU)}

Mengingat luasnya dinamika di sebagian besar ekonomi Asia, sangat penting untuk secara periodik meninjau komposisi ACU untuk memastikan bahwa hal tersebut mencerminkan realitas ekonomi saat ini. Jumlah komponen setiap mata akan tetap sedangkan kontribusi itu untuk ACU akan bervariasi dengan nilai tukar. Sebagai penilaian mata uang (depresiasi), akan ada kenaikan (penurunan) dalam kontribusi mereka untuk ACU. Ini akan memastikan bahwa ACU menangkap perubahan relatif dalam kegiatan ekonomi dan kinerja di wilayah tersebut secara efektif dan dinamis.

\section{V.2. Kerjasama Moneter dan Nilai Tukar}

Sebuah pergerakan menuju ACU akan membutuhkan tingkat kerjasama moneter yang signifikan dan pertukaran di antara negara peserta. Mengingat perbedaan dalam kebijakan nilai tukar dan tingkat inflasi di antara negara-negara tersebut, sebuah sistem yang ketat sebagai ERM tidak akan layak. Beberapa proposal alternatif lainnya telah disebutkan, masing-masing memiliki itu keuntungan dan kerugian. 
Williamson (1999) mengusulkan bahwa ekonomi Asia dapat mengadopsi mata uang bersama mempatok vis-'a-terhadap dolar AS, Euro dan Yen Jepang. Hal ini akan menstabilkan nilai tukar baik secara internal maupun vis-'a-vis lainnya mitra dagang utama, Euro Area dan AS Di bawah pengaturan ini mata uang anggota memiliki seperangkat bobot berdasarkan saham perdagangan regional. Anggota mengumumkan paritas pusat vis-'a-vis keranjang dan berjanji untuk menjaga paritas pusat dalam sebuah band yang dipilih secara sepihak. Paritas pusat dan band diperbolehkan untuk merangkak dalam menanggapi perubahan mendasar. Dalam menanggapi serangan spekulasi besar negara diijinkan untuk menangguhkan sementara pasak dengan janji untuk kembali secepat mungkin.

Keuntungan terbesar dari pengaturan ini adalah bahwa hal itu memungkinkan koeksistensi berbagai rezim nilai tukar mengambang yang berlaku di regional seperti yang dikelola di India, Thailand dan Singapura, float independen di Korea dan pasak di Cina. Lebih jauh lagi, sementara koordinasi kebijakan dan pengawasan berdasarkan pengaturan karena paritas dipilih secara sepihak dan band, pengaturan itu sendiri bertindak sebagai katalis bagi konvergensi yang lebih besar dan stabilitas nilai tukar, yang diperlukan untuk bergerak menuju masa depan mata uang bersama seperti yang ditunjukkan oleh Kawai dan Takagi (2003). Namun, masalah utama dalam pengaturan ini merupakan adopsi dari bobot daerah umum terhadap mata uang target. Jika perdagangan saham beberapa negara peserta itu (berat) vis-'a-vis negara-negara target yang sangat berbeda dari daerah secara keseluruhan maka perubahan nilai tukar bilateral dari mata uang target akan memiliki dampak yang miring pada negara-negara ini dan mereka akan kehilangan daya saing ekspor.

Pengaturan alternatif lain yang disarankan oleh Oh dan Harvie (2001) analisis potensi mereplikasi EMS's Exchange Rate Mekanisme di kawasan Asia, dengan perbedaan penting. Dalam pengaturan ini, Unit Mata Uang Asia serupa dengan akan ditempatkan. Nilai tukar negara anggota The "akan $\pm 15 \%$ dari paritas pusat ditentukan oleh otoritas. Pengaturan semacam itu dilengkapi dengan beberapa manfaat. Ini akan secara signifikan mengurangi volatilitas kurs nominal serta nilai tukar riil efektif (REER) antarregional sebagai akibat dari perubahan paritas intra dan tingkat yang lebih besar pergerakan bersama nilai tukar intra. Ini juga akan mendorong lebih cepat integrasi ekonomi dan moneter di wilayah tersebut. Namun, karena target adalah keranjang mata uang negara anggota, penyusunan kembali antara mata uang utama di luar keranjang tidak akan tercermin dalam nilai tukar bilateral. Di sisi lain jika Dolar AS terdepresiasi terhadap Euro tapi bukan Yen Jepang kemudian ekspor dari negara-negara dipatok terhadap dolar AS akan menjadi lebih kompetitif di tanah Euro dibandingkan dengan ekonomi-ekonomi Asia. Demikian pula, jika Yen Jepang dinilai sebesar 10\% terhadap Dolar AS dan Jepang memiliki berat 50\% di ACU, maka anggota ACU lain 
akan mengalami apresiasi 5\%, yang dapat mengurangi daya saing mereka vis-"a-vis dolar lainnya blok negara.

Dornbusch dan Park (1999) menyatakan gagasan kerja sama moneter antara negara Asia dengan Yen Jepang sebagai jangkar mata uang, peran yang dilakukan oleh Deutsche Mark Jerman di bawah ERM. Namun, mengingat bahwa ekonomi Jepang belum sehat dan stabil dalam beberapa tahun terakhir ini mungkin sulit untuk mendorong usulan ini. Selain itu pengaturan tersebut akan melibatkan hilangnyadaya saing ekspor Asia vis-'a-vis blok dolar lain seperti Mercosur dan NAFTA jika Yen Jepang berapresiasi terhadap Dolar AS.

\section{V.3. Membangun Suatu Sistem Negara Pusat}

Salah satu alasan sering dikutip untuk integrasi moneter yang sukses di Eropa adalah peran sentral yang dimainkan oleh Jerman. Dipercaya secara luas kehadiran mata uang kuat, Deutsche Mark, yang bertindak sebagai jangkar nominal dalam EMS, memfasilitasi integrasi tersebut. Selain itu Mark Deutsche didukung oleh Bundesbank yang berfokus pada stabilitas harga dan menciptakan komite kebijakan moneter yang independen, ciri yang telah menjadi merek dagang dari bank sentral modern. Sementara di belakang peran yang dimainkan oleh Jerman tampaknya menjadi penting bagi integrasi Eropa, pada waktu tersebut peran tidak direncanakan dan, ketika ada, sengaja di underplayed. Secara formal, EMS adalah satu set pengaturan nilai tukar bilateral tanpa mata uang pusat. negara-negara ekonomi kuat dan lemah yang tunduk pada kewajiban yang sama dan aturan intervensionis. Munculnya Mark Deutsche sebagai jangkar nominal waktu beberapa tahun dan difasilitasi oleh manajemen moneter yang tidak bertanggung jawab oleh negara-negara besar lainnya di wilayah tersebut, yang menyebabkan serangan spekulatif terhadap mata uang mereka dan melemahkan posisi mereka.

Dalam konteks Asia, sementara memang benar bahwa beberapa bentuk kepemimpinan negara yang diinginkan, kepemimpinan tersebut tidak harus dilihat intimidasi dan harus menjadi tidak seimbang. Dalam melakukan usaha tersebut, sensivitas politik dan sejarah, serta konfigurasi kekuasaan saat ini harus diingat. Saat Jepang terus menjadi pemain utama di wilayah ini, Cina dan India telah mulai meningkat tantangan serius untuk hegemoni Jepang. Oleh karena itu kohesif pergerakan menuju integrasi Asia yang lebih besar harus terbentuk pada beberapa negara terkemuka. Tidak adanya pengaruh pusat tunggal memastikan bahwa kepemimpinan seimbang. 


\section{V.4. Penguatan Inisiatif Chiang Mai dan Dana Obligasi Asia}

Pada pertemuan ASEAN+3 Menteri Keuangan yang diadakan di Istanbul pada bulan Mei 2005, telah diputuskan oleh negara-negara yang berpartisipasi untuk membuat beberapa perubahan dalam struktur CMI yang ada. Selain menyetujui untuk mengintegrasikan pengawasan ekonomi ke dalam CMI juga untuk mengembangkan mekanisme pengambilan keputusan kolektif sebagai langkah pertama menuju multilateralisasi. Hal itu juga memutuskan untuk memperluas ukuran perjanjian bilateral dan meningkatkan jumlah negara dapat bertransaksi tanpa program IMF.

Sedangkan jumlah yang negara dapat bertransaksi tanpa dikenakan program IMF telah ditingkatkan dari 10\% menjadi 20\%, tidak banyak kemajuan yang telah dibuat pada isu-isu lain. Ukuran gabungan dari jaringan BSas telah meningkat dari $\$ 365$ milliar pada bulan April 2004 menjadi \$83 milliar pada bulan Juli 2007. langkah-langkah yang kuat perlu dilakukan untuk lebih meningkatkan kerjasama ini. Salah satu cara yang mungkin adalah untuk mengundang anggota baru seperti India, yang telah hampir \$300 milliar sebagai cadangan. Selain itu, hampir semua swap bilateral dinegosiasikan antara Cina, Jepang, Korea dan negaranegara ASEAN. Anggota ASEAN yang lebih kecil seperti Brunei, Kamboja, Laos, Myanmar dan Vietnam hanya ditutupi oleh Perjanjian Swap ASEAN, yang memiliki korpus paling sedikit $\$ 2$ miliar.

Demikian pula Asian Bond Fund juga perlu ditingkatkan dari itu ukuran saat ini dan cakupan. negara-negara baru seperti India serta ASEAN lainnya ekonomi bisa diajak untuk bergabung denagn pendanaan tersebut. Ada kebutuhan serius untuk memperkuat korpus dana yang tersedia dengan ABF untuk itu untuk memainkan peran penentu dalam memperdalam integrasi pasar modal di daerah. Dengan demikian bank sentral negara-negara peserta harus mengikat sumber daya lebih besar untuk pendanaan. Dalam bentuk ini saat ini ABF dikelola oleh Bank of International Settlements (BIS) asosiasi bank sentral global. Dengan demikian usaha investasi dana-dana ini terutama di tangan gubernur bank sentral yang cenderung lebih konservatif dan rela berkorban kembali untuk likuiditas. Untuk menjamin pembangunan yang lebih besar dari pasar modal internasional di regional, partisipasi sektor swasta dalam bentuk investasi bankir dan institusi investor dalam ABF perlu didorong.

\section{IV.5. Kerjasama Pendanaan Moneter Asia}

Selain memperkuat Chiang Mai Initiative dan Asian Bond Fund, negara-negara Asia dapat menciptakan pendanaan regional dalam mata uang ACU. Dana seperti ini dapat digunakan untuk memfasilitasi intervensi di pasar mata uang, efek likuidasi antara bank sentral dan 
mengelola fasilitas kredit jangka pendek yang terkait dengan kerjasama nilai tukar. Dana ini dapat dibuat dengan menekan jumlah besar cadangan devisa negara-negara Timur dan Asia Selatan. Setiap negara anggota dapat berkontribusi dalam persentase tertentu dari cadangan devisa mereka ke dalam dana tersebut. Mengingat bahwa kepemilikan cadangan total ekonomi dipertimbangkan adalah lebih menjadi \$ 3 triliun, bahkan jika negara-negara ini memberikan kontribusi $10 \%$ dari kepemilikan cadangan mereka, dana dengan lebih dari \$300 milyar akan dibuat.

Jika kurs mata uang yang berpartisipasi jatuh terlalu jauh, Asian Moneter Cooperation Fund (AMCF) bisa membeli jumlah mata uang di pasar valuta asing, dan jika naik terlalu jauh, AMCF bisa menjual cukup banyak mata uang untuk menurunkan nilai tukar. Atau, AMCF juga dapat mengeluarkan mata uang paralel, Asia Currency Unit, yang akan menjadi komposisi tertimbang mata uang negara-negara anggota. obligasi dalam mata uang ACU dapat didorong dan kliring regional dan mekanisme pembayaran dapat dibentuk untuk transaksi ACU. Seiring waktu, AMCF dapat dikonversi ke Asia Central Bank dan berperan melaksanakan kebijakan moneter di Asia Timur dan Asia Selatan.

Korpus yang tersedia dapat digunakan untuk membiayai beberapa kebutuhan pembangunan daerah. Utama di antara bisa menggunakan pembiayaan investasi infrastruktur. Banyak negara di wilayah seperti India, Vietnam, Indonesia, dll menghadapi defisit infrastruktur besar, terutama dalam infrastruktur fisik seperti jalan raya, listrik, bandar udara dan lain-lain AMCF bisa mengalokasikan dana dalam mata uang ACU, untuk proyek-proyek tersebut. Hal ini tidak hanya akan membantu mengurangi defisit infrastruktur besar di wilayah tersebut tetapi juga mempromosikan penggunaan publik dan sektor swasta ACU. kebutuhan perkembangan lain yang dapat dibiayai oleh AMCF termasuk infrastruktur sosial seperti kesehatan dan pendidikan, perlindungan lingkungan dan penguatan sektor keuangan, dan lain-lain.

\section{IV.6. Penerapan Sistem Pengawasan Daerah yang Efektif}

Salah satu tantangan terbesar yang dihadapi ACU adalah pelaksanaan mekanisme pengawasan yang efektif di regional. Keberadaan mekanisme pengawasan ASEAN +3 perlu diperkuat secara signifikan jika bertindak sebagai instrumen untuk kerjasama ekonomi dan moneter yang lebih besar. Menurut Kenen dan Meade (2008) dan Girardin (2004) perekonomian Asia perlu menjauh dari prinsip "non-intervensi di negara-negara lain dan aktif memberikan pendapat mereka tentang kebijakan diikuti di negara-negara anggota. Sementara pendekatan konfrontatif yang melibatkan kritik langsung dari kebijakan negara-negara tetangga mungkin 
tidak layak pada tahap ini, beberapa lainnya seperti tindakan yang kurang konfrontatif, dapat dilakukan. Kenen dan Meade (2008) dan Grenville (2004) menyarankan suatu mekanisme dimana analisis dan rekomendasi dari tim pengawasan independen diletakkan sebelum negara anggota dan pemerintah diperbolehkan untuk merespon kiriman. Debat sehat pada isu-isu utama sektor makro ekonomi dan keuangan negara yang berdampak pelaporan adalah suatu keharusan untuk pengawasan yang lebih baik dan koordinasi yang lebih besar. Hal ini menggarisbawahi perlunya kritik konstruktif yang lebih besar di antara negara-negara anggota bahkan jika itu datang pada pembiayaan maka kembali ke tradisi Asia untuk tidak ikut campur dalam urusan tetangga.

\section{IV.7. Integrasi Pasar Barang dan Jasa yang Lebih Besar}

Moneter kerjasama di Eropa dicapai dengan tujuan untuk mengubah Eropa menjadi pasar yang benar-benar bersatu. Perjanjian tahun 1957 pendiri Uni Eropa Roma telah membentuk Serikat Pabean dan hambatan perdagangan barang dan jasa secara signifikan berkurang selama empat dekade berikutnya. Jadi kerjasama perdagangan dimulai jauh sebelum kerja sama keuangan. Di sisi lain, dalam kerjasama Asia Timur keuangan memimpin terutama sebagai respon terhadap krisis keuangan tahun 1997. Kerjasama keuangan seperti sekarang perlu dilengkapi dengan kerjasama perdagangan yang lebih besar di wilayah ini. Dikarenakan penerapan kerjasama Doha Development Agenda sangat terbatas, negara-negara di regional perlu untuk meningkatkan kerjasama perdagangan melalui perjanjian bilateral daripada mengandalkan perundingan perdagangan multilateral. Status berbagai perjanjian perdagangan di regional tersebut. Hal ini dapat jelas terlihat bahwa sementara beberapa negara seperti Jepang telah dengan penuh semangat mengejar perjanjian perdagangan bilateral, negaranegara lain seperti Filipina dan Indonesia tertinggal.

Perjanjian perdagangan bebas preferential atau cenderung untuk mendorong kerjasama yang lebih besar karena mereka lebih fleksibel, luas dan relatif mudah dicapai. Integrasi pasar yang lebih besar melalui PTA / FTA tidak hanya akan menyediakan akses pasar yang lebih luas di seluruh wilayah tetapi juga akan memberikan efisiensi melalui persaingan. Dalam beberapa kasus perjanjian perdagangan dapat digunakan sebagai strategi untuk mendorong reformasi domestik. Dasar untuk perjanjian ekonomi Asia terletak dalam meningkatkan kepentingan ekonomi bersama berdasar atas saling ketergantungan ekonomi. «Model angsa terbang» membantu membangun rantai vertikal di seluruh wilayah dengan mendorong mobilitas modal dan transfer teknologi, sehingga merumuskan pertukaran intra-regional tingkat tinggi. Saling ketergantungan ekonomi tersebut dapat lebih dieksploitasi melalui lebih bebas / perjanjian perdagangan preferensial di antara wilayah tersebut. Dengan integrasi intra-Asia lebih besar 
perdagangan, siklus bisnis akan lebih berkorelasi berbagai negara dan akan lebih mudah bagi yang terakhir untuk terlibat dalam kerjasama nilai tukar, yang sangat penting untuk bergerak menuju suatu Unit mata uang Asia.

\section{KESIMPULAN}

Pembentukan integrasi ekonomi, seperti pengaturan ekonomi regional, berfungsi terutama untuk membantu mendorong stabilitas di seluruh wilayah. Pembentukan integrasi ekonomi dapat diperkuat oleh gagasan mata uang tunggal. Kelayakan integrasi ekonomi dan mata uang tunggal adalah fokus utama dari penelitian ini. Kami menyelidiki apakah ada ruang untuk variabel OCA dalam menjelaskan ERV dalam kasus ASEAN-5 +3 untuk periode 1970-2008

Hasil penelitian ini memberikan beberapa bukti bahwa ASEAN-5 +3 dianggap tidak benarbenar siap untuk membentuk KSO. Ini menguatkan pendapat yang ada bahwa perbedaan dalam struktur ekonomi dan kebijakan atas lingkungan yang asing menjadi beberapa hambatan dan menantang regional untuk melakukan sinkronisasi dalam waktu berikut.

Dampak positif AS untuk ERV yang terjadi dalam ASEAN-5 +3 ekonomi menunjukkan adanya kondisi yang tidak tepat untuk membentuk KSO karena tidak ada guncangan yang sama di seluruh negara serikat moneter yang berpartisipasi. Dalam kondisi seperti itu, itu akan mendorong biaya forgoing nilai tukar sebagai guncangan yang mengganggu mekanisme.

Hal ini layak dibantah bahwa negara-negara yang diamati masih melindungi rezim mereka karena mereka percaya bahwa mereka mulai membangun sistem moneter yang mampu menyerap goncangan apapun yang mungkin dalam hal dari ukuran mereka. Singkatnya, ASEAN$5+3$ negara dianggap memenuhi persyaratan untuk membentuk area mata uang optimum yang mana keuangan mereka dapat stabil.

Berdasarkan uji Granger, kami menemukan bahwa hanya Thailand, Taiwan, Jepang, dan Cina yang memberikan efek jangka pendek untuk variabel yang diamati. Sedangkan dampak jangka pendek ERV pada PDB dan AS yang positif bagi negara-negara tersebut. Sementara itu dalam kasus Thailand, PDB telah meningkat terhadap AS. Ini merupakan fakta bahwa ekonomi Thailand akan mengalami goncangan melalui fluktuasi di dalam PDB. Selanjutnya, Indonesia, Malaysia, dan Phillipinnes tampaknya tidak menunjukkan hubungan sebab akibat antara variabel OCA dan ERV.

Sebuah langkah sukses menuju OCA pada dasarnya perlu mengatasi sejumlah kendala yang biasanya berhubungan dengan integrasi ekonomi dan moneter yang lebih besar, yaitu lembaga yang lemah, tidak memadainya Pengawasan di regional, Pasar Obligasi Tertinggal, 
Beragam Kurs rezim, Ekonomi, Heterogenitas Sejarah dan Politik. Pada sisi lain, sebuah langkah sukses menuju Unit mata uang Asia perlu untuk mengatasi kendala di atas, seperti Periodic Review dari ACU, Kerjasama Moneter dan Nilai Tukar, membangun suatu sistem Negara Pusat, Memperkuat Chiang Mai Initiative dan Asian Bond Fund, Asian Moneter Cooperation Fund, menerapkan Sistem Pengawasan Regional yang Efektif, Integrasi pasar Barang dan Jasa yang lebih besar. 


\section{DAFTAR PUSTAKA}

Bystrom, Hans N. E. karin Otofsdotter, Lars Soderstrom. Is China an Optimum Currency Area? Journal of Asian Economics 16. 2005. 612-634.

Eicherngreen, Barry. -tahun- Chapter 7, Parallel Process? Monetary Integration In Europe and Asia. -journal of Economics

Frankel, Jeffrey, and Andrew Rose. An Estimate of The Effect of Common Currency on Trade and Income. The Quarterly Journal of Economics, May 2002.

Grauwe, Paul de. - tahun- , Chapter 6, Asian Monetary Unification: Lessons Froom Europe. journal of Economics

Grauwe, Paul de. 1996. International Money Postwar Trends and Theories. Oxford University

Press Inc. : New York

Huang, Yin, Feng Guo. Is Currency Union Feasible Option In East Asia? A Multivariate Structural VAR Approach. Research In International Business and Finance 20. 2006. pg 77-94.

Kawasaki, Kentaro. A possibility of Creasing A Common Currency Union In East Asia. -journal of Economics

Kettell, Brian. 2002. Economics for Financial Markets. Butterworth-Heinemann: Oxford.

McKinnon, Ronald. Optimum Currency Areas, and Key Currencies: Mundell I versus Mundell II.

Forthcoming Journal of Common Market Studies. August 2004.

Mishra, Ritesh Kumar, Chandan Sharma. Real Exchange Rate Behavior and Optimum Currency Area in East Asia: Evidence from Generalized Purchasing Power Parity. International Review of Financial Analysis 19. 2010. 205-213.

Mundell, Robert A. 1961. Optimum Currency Areas. American Economic Review, 51, 657-665 Mundell, Robert. 2005. The Case for A World Currency. Journal of Policy Modeling.

Ricci, Luca Antonio. A model of An Optimum Currency Area. Recent Development in International Money and Finance. Vol 2. March 14, 2008.

Mussa, Michael, Paul Masson, Alexander Swoboda, Esteban Jadresic, Paolo Mauro, and Andrew

Berg. 2000. Exchange Rate Regimes In An Increasingly Integrated World Economy. International Monetary Fund: Washington D. C.

Quah, Chee-Heong. The Feasibility of East Asian monetary Union As An Optimum Currency Area. IJAPS Vol. 5, No. 2. 65 - 90. 2009

Rosenberg, Richard. 2010. Does Microedit Really Help Poor People? Focus Note: Washington D. C. 
Saxena, Sweta Chaman. Can South Asia Adopt a Common Currency. Journal of Economics Sin, Lew Yuen, and Ku A. T. L. Are Countries of Association of South East Asian Nations (ASEAN) Candidates of Optimum Currency Area for Monetary Union? A Structural Var Approach. Review of Applied Economics, Vol 2, No. 2. 2006

Zhang, Zhaoyong, Kiyotaka Sato, and Michael McAleer. Is East Asia An Optimum Currency Area? 